\title{
A NOTE ON EDITIONS AND TRANSLATIONS
}

The very great majority of the tonadillas remain unedited. Readers interested in playing through or performing this repertory have several options:

1. For the adventurous, an increasing number of original eighteenth-century tonadilla manuscripts have been digitized by the Biblioteca Histórica Municipal de Madrid, the major archival holder of this repertory. These may be consulted, and in some cases downloaded as PDF files, directly from the BHMM catalog website, http://catalogos.munimadrid.es/cgi-bin/historica/. There is no separate listing of the digitized tonadillas, so it is helpful to know what one is looking for in advance. Limited browsing may be done by choosing "búsqueda avanzada" and then typing in a composer name and the keyword "tonadilla." The manuscripts consist of performance parts only; there are no full scores. All are, obviously, unedited, and they come in a variety of conditions, from lamentable to excellent.

2. The Biblioteca Nacional de España has recently digitized some 160 tonadillas by Blas de Laserna, transcribed by Francisco Asenjo Barbieri between 1874 and 1894, which are downloadable. This collection may be browsed at the BNE online catalog (http://catalogo.bne.es/) by using the following search terms: Todos los campos: Barbieri-Autor: Laserna-Tipo de documento: Partituras impresas y manuscritas. These are beautifully hand-transcribed scores; performance parts would have to be extracted from them.

3. Those who wish to work from conventionally published editions have a variety of options, with a range of scholarly engagement and completeness, from Subirás many piano-vocal arrangements to careful score transcriptions by musicologists. Almost all of the latter will require a certain amount of 
cutting and pasting in order to arrive at usable performance parts. I have compiled a list of all these options, including extant editions from Barbieri's day to our own, in "Editions of Tonadillas (1874-present)," available online at the eScholarship repository of the UCLA Department of Musicology (http:// escholarship.ucop.edu/uc/search?entity=hasom_musicology_me).

I have also made complete editions of fourteen of the tonadillas that I discuss in this book, downloadable as scores and parts from the same repository.

I wrote the entire first draft of this book in Spanish. What you are reading in these pages, with the exception of most of the introduction, some passages in chapter 3 , and sentences like this one, is a translation.

Not a few of my friends and colleagues, Spaniards as well as estadounidenses, have asked me with a certain exasperation why I would do something so absurd: I am not a native speaker, and my Spanish, while good, is not perfect. To a greater or lesser degree, despite years of serious and ongoing study, I am doomed always to translate internally from and to my native language. In effect, then, this is really a retranslation.

I did it out of idealism and out of love, as the most profound way I knew of imagining the culture and the people I was studying. The recognition of the impossibility of reaching perfect linguistic or historical unity with my object of study has not been the less painful for having been inevitable. In the end it is precisely this pain that has become the best justification for the absurdity. The experience of alienation, lived laboriously, word by word, culture clash by culture clash-my own longing for understanding that has always swum upstream against realityhas given me some small understanding of the thousand strategies used by the Spanish theater to negotiate similar cracks and breakdowns in human relations, and of the possibilities and limitations of representation.

I hope very much that this perspective, rooted in a certain personal romanticism, achieved in a truly baroque manner, and presented in the modern format of the academic monograph, will be of value for my postmodern readers.

Sources prior to 1850 appear in Spanish and English translation. Post-1850 sources are in English only. All translations from Spanish and French are mine unless otherwise indicated.

Noemi Silva Gosálvez, who reviewed my transcriptions, has advised me in the following clarifications: in places where sense might be obscured by an antique usage, a clarification appears in square brackets; where an old usage seems to be an error, it is followed by [sic], and by a clarification when that is called for. I went against her advice in adhering to the original orthography and accentuation of pre-1900 sources, including the music examples. These variances are not difficult to follow for the reader of modern Spanish, since what has changed is 
usually the spelling but not the pronunciation. For example, "haver" or "aver" might replace the modern "haber," "muger" the modern "mujer," "si" the modern "sí," or "quasi" the modern "casi." In the tonadilla manuscripts, the copyists very frequently used the shorthand "q.e" for "que" and "porq.e" for "porque," and they habitually spelled Italian musical indications in rather Hispanized ways, for example, "Allegreto." 
This page intentionally left blank 